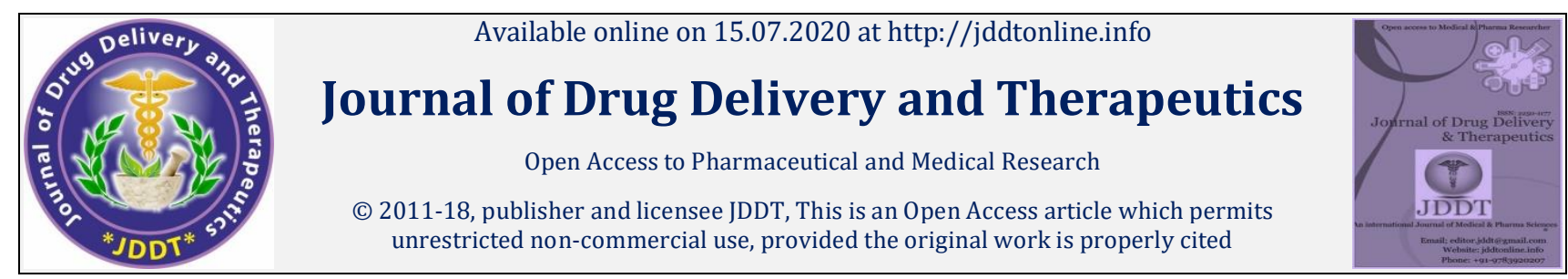

Open $\odot$ Access

Research Article

\title{
Apoptotic Effects of Prunus persica (L) Batsch Leaves against Breast Cancer Cell Line (MDA-MB-231) and Cervical Cancer Cell Line (HeLa) In Vitro
}

\author{
Bhat Firdous Ahmad 1*, Shafi Sabeeha1, Hilal Nazia², Bhat Showkat Ahmad1', Rafiqee Aneequa1 \\ ${ }^{1}$ Department of Pharmaceutical Sciences, University of Kashmir, Hazratbal Srinagar-190006, Jammu and Kashmir, India \\ 2 Department of Biotechnology, University of Kashmir, Hazratbal Srinagar-190006, Jammu and Kashmir, India
}

\begin{abstract}
Background: Apoptosis is a normal physiological phenomenon that plays a pivotal role during embryonic development, retention of tissue homeostasis and pathology. The experimental investigation of apoptotic processes is still challenging and routinely based on the assessment of molecular events like chromatin fragmentation and caspase enzyme activity. The present study was conducted to evaluate the apoptosis inducing effect of the Methanol, aqueous and chloroform extracts of Prunus persica leaves.

Methods: Different extracts were obtained by cold extraction process using Methanol, water and Chloroform as solvents. Crude extracts were screened for different phytochemical constituents like flavonoids, tannins, sugars, saponins, and glycosides etc. The apoptotic effect of Prunus persica leaves was examined by DAPI staining assay against MDA-MB-231 (Human breast cancer cell line) and HeLa (Human cervical cancer cell line).

Results: The results of the studies revealed that the Chloroform extract have tremendous apoptotic activity on MDA-MB-231 cells and methanolic extract have good apoptotic activity on HeLa cells. Nuclear morphological changes assessed by DAPI shows changes in morphology, apoptotic body formation, cell shrinkage, nuclei that were broken into discrete fragments and cell budding that resulted in cells of various sizes.

Conclusion: The phytochemical screening reveals the presence of alkaloids, tannins, Saponins, steroids and flavonoids. The Chloroform extract has shown more effectiveness and less toxicity against MDA-MB-231 and Methanol extract was more apoptotic against HeLa in comparison to others. The present findings clearly indicated that Prunus persica leaves showed dose dependant cytotoxicity.
\end{abstract}

Keywords: Apoptosis, Prunus persica, DAPI, Cancer, In Vitro

Article Info: Received 10 April 2020; Review Completed 14 June 2020; Accepted 20 June 2020; Available online 15 July 2020

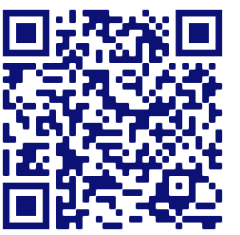

Cite this article as:

Bhat FA, Shafi S, Hilal N, Bhat SA, Rafiqee A, Apoptotic Effects of Prunus persica (L) Batsch Leaves against Breast Cancer Cell Line (MDA-MB-231) and Cervical Cancer Cell Line (HeLa) In Vitro, Journal of Drug Delivery and Therapeutics. 2020; 10(4):25-30 http://dx.doi.org/10.22270/jddt.v10i4.4124

Bhat Firdous Ahmad, Department of Pharmaceutical Sciences, University of Kashmir, Hazratbal Srinagar-190006, Jammu and Kashmir, India

\section{INTRODUCTION}

Medicinal plants serve as nature's gift to humans to help them pursue better health. Plants and their bioactive compounds are in medicinal practices since ancient times. Several medicinal plant species and their phytochemicals inhibit the progression and development of cancer 2 . Compared with the conventional cancer chemotherapy, the mixture of phytochemicals extracted from medicinal plants may have synergistic effect that targets several pathways responsible for cancer pathogenesis. The plant products and their secondary metabolites play significant roles in either activating DNA repair mechanism (p53, p51, p27, p21 genes and their protein products) ${ }^{3,4}$, Bid, Bak proteins, Bax, stimulating the formation of protective enzymes (Caspase$12,10,9,8,7,3$ ) or by inhibiting cancer cell activating proteins, enzymes and signalling pathways [Cdc2, CDK2 and CDK4 kinases, topoisomerase enzyme, cycloxigenase and COX-2 (Cycloxigenase), Bcl-2, cytokines, PI3K, Akt, MAPK/ERK,

ISSN: 2250-1177

[25]
MMP, TNK, mechanistic target of rapamycin (mTOR) ], inducing antioxidant action (antioxidant enzymes e.g. GSH, GST and GPxn), thus showing strong anticancer effects in terms of their efficacy on the above mentioned proteins, enzymes and signaling pathways 5,6 . It has been also reported that more than $50 \%$ of all modern drugs in clinical use are of natural products, many of which have been recognized to have the ability to include apoptosis in various cancer cells of human originals, there is an urgent need to develop much effective and less toxic drugs ${ }^{7}$.The high altitudes of Kashmir Himalayas with their rich biodiversity harbour about 2000 plant species.

Cancer is not a simple disease but a complex interaction between multiple signaling pathways with various target molecules ${ }^{8}$. Apoptosis consists of a series of highly organized and fine-tuned processes accompanied with structural changes in cellular and sub-cellular architecture firstly described in the 1970's by Kerr and co-workers ${ }^{9}$. 
Besides changes in energy-dependent molecular pathways, induction of apoptosis also results in characteristic and stage dependent morphological alterations, including chromatin condensation (pyknosis), cell shrinking, nuclear deformation, formation of apoptotic bodies and subsequent degradation of the apoptotic bodies by adjacent cells 10.Despite significant progress in the treatment of certain forms of cancer, it remains a major cause of death throughout the world11-13.Cancer therapy generally combines surgery, multi-therapeutic agents and ionizing radiation which induce cell cycle arrest and cell death by apoptotic, non-apoptotic mechanisms (necrosis, senescence, autophagy and mitotic catastrophe) ${ }^{\mathbf{1 4}}$. The current available methods of treatment all induce significant side effects and therefore the need for alternate adjuvant therapies has arisen ${ }^{\mathbf{1 5}}$.Natural products are extremely an important source of medicinal agents. Although there are some new approaches to drug discovery, such as combinatorial chemistry and computer based molecular modeling design, none of them can replace the importance of natural products in drug discovery and development ${ }^{16,17}$. The potential of using the natural products as anticancer drugs was recognized in 1950's by U.S.Natural Cancer Institute (NCI) since 1950 major contributions have taken for the discovery of naturally occurring anticancer drugs ${ }^{18 .}$

The Valley of Kashmir known for its beauty all over the world is also rich in herbal and floral wealth. The valley of Kashmir is very rich in high value and high altitude aromatic and medicinal plants. Kashmir valley has a great potential for establishing pharmaceutical and essential oil industry based on these high-value plant species ${ }^{19}$. Prunus persica (L) Batsch (family Rosaceae) is a deciduous tree or large shrub with lanceolate tapering leaves and pink flowers native to China, Iran and in African and south American countries. The various parts of the plant have reported for its useful medicinal properties like antioxidant, antiacetylcholinesterase , anti-inflammatory , hypermenorrhea, dysmenorrhea, leiomyoma, infertility, anti-tumour promoter and anti-oketsu syndrome (stagnation of blood circulations), anthelmintic, laxative, sedative, antimalarial, hepatoprotective, antiasthmatic, anticoagulant, antifungal, cholinomimetic, calcium antagonist and anti-allergic inflammatory properties ${ }^{20}$.In the present study, in vitro Apoptotic activity of crude extracts of leaves of Prunus persica has been investigated against MDA-MB-231(Human breast cancer cell line) and HeLa (Cervical cancer cell line) using DAPI Staining assay.

\section{MATERIALS AND METHODS}

\section{Plant collection and Identification}

The leaves of the plant Prunus persica was collected from the district Budgam (Bugam Area) in june 2017. It was authenticated by the curator, department of Taxonomy, University of Kashmir Srinagar under voucher specimen No. 2602-(KASH) Herbarium, University of Kashmir, $22 / 06 / 2017$. A sample specimen of collected material was deposited in herbarium for future reference. Leaves of plant were collected, washed under running tap water and dried under shade and ground into coarsely powder in the electronic grinder. The powder was stored in plastic bags at room temperature under low humidity condition.

\section{Preparation of Extracts}

The drying of the leaves was followed by extraction process. The solvents used for extraction were Chloroform, methanol and water. The extraction was done by the process of cold maceration. $200 \mathrm{mg}$ of leaves were extracted with Chloroform $(500 \mathrm{ml})$ for $18-20$ hours with occasional shaking. The extract was concentrated under reduced pressure using rota vapour. The marc so obtained was subsequently extracted with methanol $(320 \mathrm{ml})$ for 18-20 h. The extract so obtained was concentrated using rotavapour. The marc left behind was then extracted with water $(300$ $\mathrm{ml}$ ) for 6-8 $\mathrm{h}$. The extract was then concentrated by heating on water bath. All the extracts were stored at $4^{\circ} \mathrm{C}$.The extracts obtained were weighed and their percentage yield was calculated. The colour \& consistency of the extracts were noted.

\section{Phytochemical screening}

Chemical tests were performed for the methanol, water and chloroform leaf extracts of the plant using standard procedures to identify the presence of various phytochemicals viz: alkaloids, phytosterols, flavonoids, cardiac glycosides, anthraquinone glycosides, tannins, triterpenoids, saponins, carbohydrates, proteins and amino acids following standard described by Raman, 200621,22:

\section{1) Tests for Alkaloids}

\section{a) Hager's test:}

To a few ml of filtrate sol.1 or $2 \mathrm{ml}$ of Hager's reagent (saturated aqueous solution of picric acid) were added. A prominent yellow precipitate indicated the test as positive.

\section{b) Wagner's test:}

To a few ml of filtrate, few drops of Wagner's reagent were added by the side of the test tube. A reddish - brown precipitate confirmed the test as positive.

\section{2) Tests for Tannins}

\section{Gelatin test:}

To $5 \mathrm{ml}$ of extract solution $2 \mathrm{ml}$ of solution of gelatin containing $10 \%$ sodium chloride was added to it. White precipitate indicated the presence of phenolic compounds.

\section{3) Tests for Flavonoids}

\section{a) Lead Acetate Test:}

To $1 \mathrm{ml}$ of the extract solution added few drops of $10 \%$ lead acetate, formation of yellow precipitate confirmed the presence of flavonoids.

\section{b) Ferric chloride test:}

Extract solution when treated with few drops of Ferric chloride solution would result in the formation of blackish red colour indicating the presence of flavonoids.

\section{4) Tests for Glycosides}

\section{Borntrager's test:}

To $2 \mathrm{ml}$ of filtered hydrolysate, $3 \mathrm{ml}$ of chloroform was added and shaken, chloroform layer was separated and 10\% ammonia solution was added to it pink colour indicated the presence of glycosides.

\section{5) Tests for Saponins}

\section{Olive oil test:}

Few drops of olive oil were added to $2 \mathrm{ml}$ of the test solution and shaken well. The formation of a soluble emulsion confirmed the test.

\section{6) Tests for Steroids and Triterpenoids}

\section{Salkowski Test:}

$2 \mathrm{ml}$ of extract solution was shaken with $1 \mathrm{ml}$ of chloroform and a few drops of concentrated sulfuric acid were added 
along the side of the test tube. The test tube was shaken for few minutes. A red brown color formed at the interface indicated the test as positive for triterpenoids.

\section{7) Tests for Carbohydrates}

\section{Benedict's test:}

To $0.5 \mathrm{ml}$ of filtrate, $0.5 \mathrm{ml}$ of Benedict's reagent was added. The mixture was heated on a boiling water bath for $2 \mathrm{~min}$. A characteristic coloured precipitate indicated the presence so sugar.

\section{8) Tests for Proteins and Amino-Acids}

\section{Biuret test:}

An aliquot of $2 \mathrm{ml}$ of filtrate solution was treated with one drop of $2 \%$ copper sulphate solution. To this, $1 \mathrm{ml}$ of ethanol (95\%) was added, followed by excess of potassium hydroxide pellets, pink colour in the ethanolic layer indicated the presence of proteins.

\section{Cell lines and culture:}

The Breast cancer cell line (MDA-MB-231) and human Cervical adenocarcinoma cell line (HeLa) cancerous cell lines were procured from national centre for cell sciences (NCCS), Pune. Stock cells were cultured in dulbecco's modified eagle's medium (DMEM) supplemented with $10 \%$ inactivated fetal bovine serum (FBS), penicillin, streptomycin in a humidified atmosphere with 70-80\% confluency. The cells were maintained in a $\mathrm{CO}_{2}$ incubator with $5 \% \mathrm{CO}_{2}$ and $95 \%$ humidity. After receiving cells, culture was trypsinized and grown in fresh media of t-culture flasks. The t- culture flask was then marked with the seeding date, cell line, and the passage number. This cell suspension was then transferred to a new t-culture flask and allowed for incubation in $5 \% \mathrm{CO}_{2}$ at $37^{\circ} \mathrm{C} 23$.

\section{Detection of nuclear morphological changes using DAPI fluorescent dye staining assay}

The DAPI is a blue fluorescent dye which is sensitive to chromatins and very less toxic to cells, it is done to observe the nuclei changes in apoptotic cells. MDA-MB- 231 and HeLa cells were patched in 6-well dishes and maintained at $37^{\circ} \mathrm{C}$ along $5 \% \mathrm{CO}_{2}$ and incubated for $24 \mathrm{~h}$. The cells were then treated with two concentrations of each extract that were calculated on the basis of $\mathrm{IC}_{50}$ determined in the previous study of the plant. Untreated cells were used as controls which contains only the complete medium and cells. The human cervical adenocarcinoma cell line (HeLa) and Breast cancer cell line (MDA-MB-231) were grown in Eagles Minimum Essential Medium (EMEM) which contained 10\% fetal bovine serum (FBS). All cells were maintained at $37^{\circ} \mathrm{C}$, $100 \%$ relative humidity, $5 \% \mathrm{CO}_{2}, 95 \%$ air and incubated for 24 hours. After $60-80 \%$ confluency a range of different conc. of the drug extracts were added to the cell plates. Incubated the plates for 24 hours and remove the media completely. The incubation was followed by 2 washings with PBS (Phosphate Buffered Saline).Fixed the cells with 4\% PFA (Para Formaldehyde) for 8-10 minutes. (This timing is very critical and it should definitely not be for more than 10 minutes).The fixative i.e. Para formaldehyde was fully aspirated. Washed cells with 1x PBS (Phosphate Buffered Saline), 3 times, 5 minutes / wash. The cells were permealized by immersion in permealization buffer (Methanol) which should be ice cold. Waited for about 10-15 minutes (10 min in freezer).Another washing was given by PBS. Stained the cells with $50 \mu \mathrm{L} /$ well of DAPI $(1: 2000$ dilution, in 1x TBST) for 5 minutes. Observed the cells under the fluorescence microscope under $40 \times$ magnifications. The stained cells were pictured using a fluorescence microscope with the suitable excitation filter ${ }^{24}$.

\section{RESULTS}

DAPI staining was used to assess the apoptosis and necrosis of cell death in MDA-MB-231 and HeLa cells.Phytochemical screening in this study has revealed the presence of alkaloids, tannins, steroids and flavonoids(table1) etc. Extracts induced morphological changes such as cell shrinkage, rounding of cells and membrane blebbing which depict the induction of apoptosis. Supplementary photographs taken have depicted the details of DAPI staining of HeLa cells and MDA-MB-231 cells. It was noted that the number of cells showing signs of apoptosis (cells that have brightly fluoresced and fragmented nucleus) were more in extract treated groups than the control group normal cells and this may be indicative of apoptosis. Morphological changes observed in the treated cells included cell shrinkage, nuclei that were broken into discrete fragments and cell budding that resulted in cells of various sizes. After $24 \mathrm{~h}$ treatment with the plant extracts, chromatin condensation, nuclear pyknosis, increased number of nuclear body fragments and irregular edges around the nucleus were observed in treated MDAMB-231 and HeLa cells, while round, clear edged, uniformly stained cell nuclei were noted in the untreated control.It is clearly evident that different doses of extracts have induced apoptosis in cells with varying intensity in dose dependent manner. Higher concentrations of Prunus persica leaf extract appeared to cause more morphological changes, indicating that apoptosis occurred in a concentration-dependent fashion as shown in the fig 1.1 and 1.2 .

Table1: Result of preliminary phytochemical screening of leaves of Prunus persica.

\begin{tabular}{|c|c|c|c|c|}
\hline Serial No & Component & Methanolic & Aqueous & Chloroform \\
\hline 1 & Flavonoids & + & + & + \\
\hline 2 & Glycosides & + & - & + \\
\hline 3 & Alkaloids & + & + & + \\
\hline 4 & Carbohydrates & + & + & + \\
\hline 5 & Proteins & + & + & - \\
\hline 6 & Saponins & + & + \\
\hline 7 & Steroids & + & + \\
\hline 8 & \multicolumn{2}{|c|}{ Tannins } & + \\
\hline Footnote: & + sign indicates (Positive Test) while - sign indicates (Negative Test) & \\
\hline
\end{tabular}




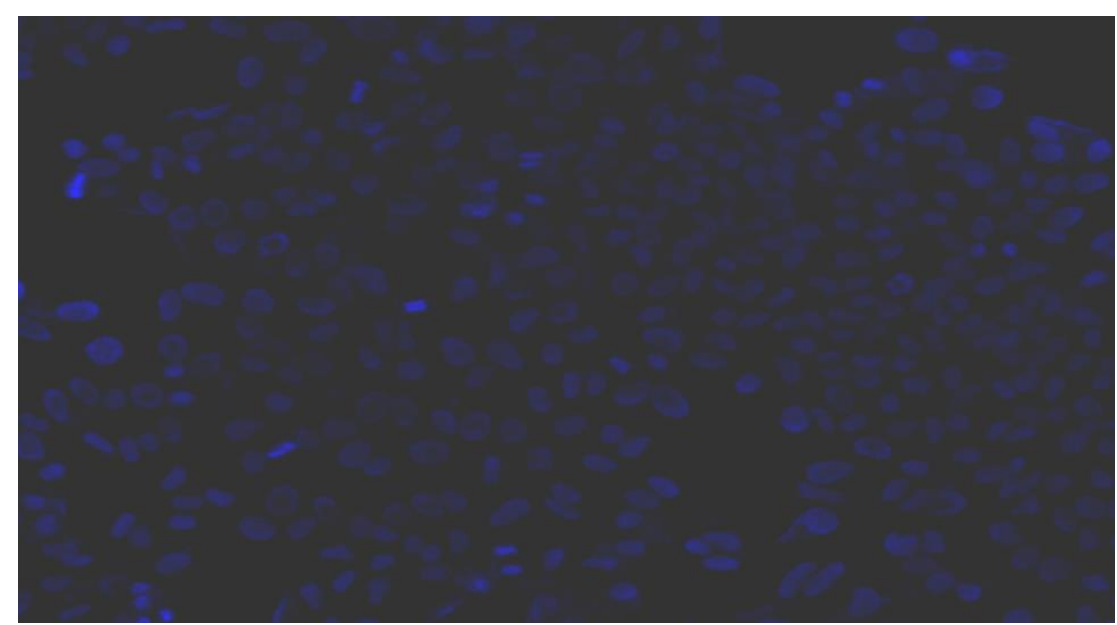

UNTREATED
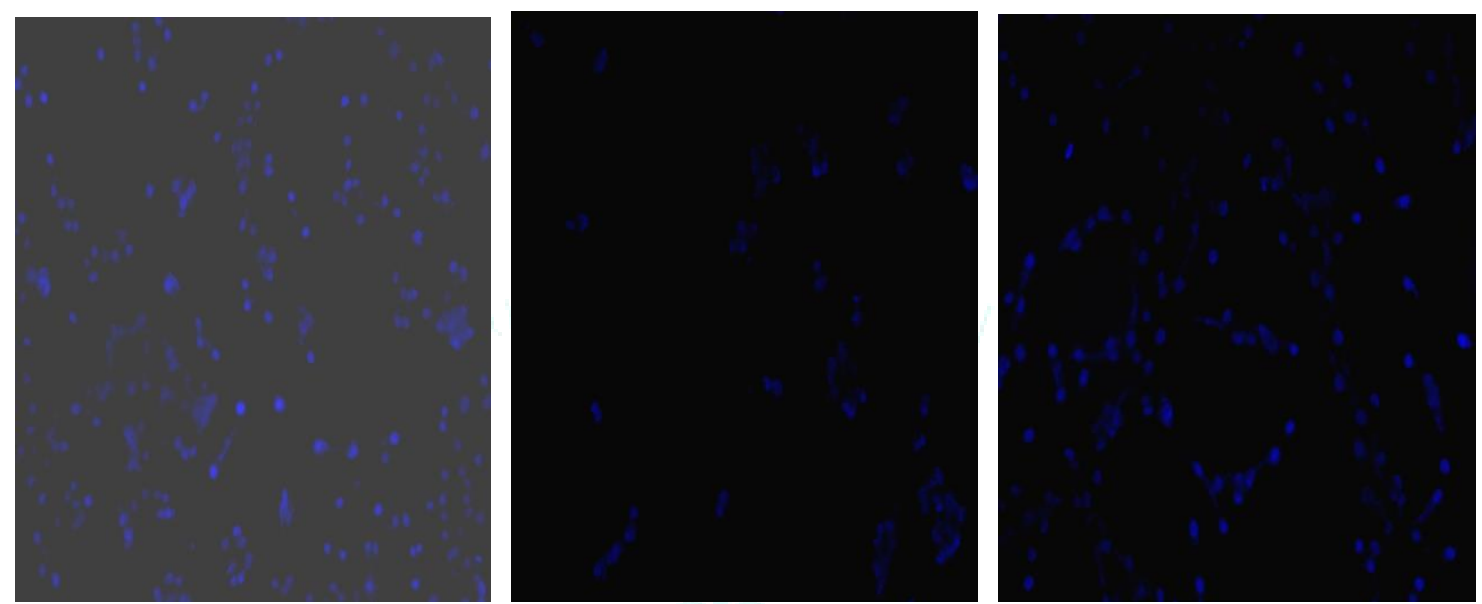

(A)

(B)

(C)
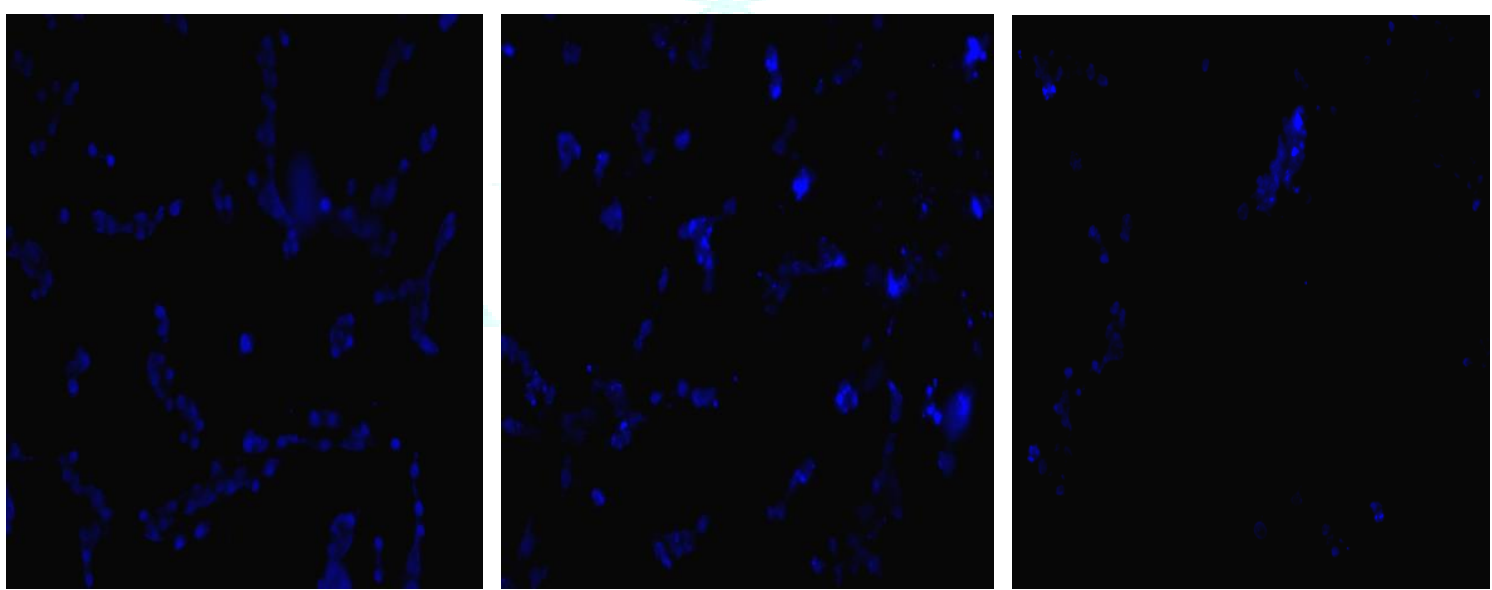

(D)

(E)

(F)

Fig. 1.1: Nuclei morphological changes of MDAMB-231 cells pre-treated with different extracts of Prunus persica(Linn)Batsch leaves followed by staining with DAPI fluorescent dye at $24 \mathrm{~h} .(\mathrm{A}) 50 \mu \mathrm{g} / \mathrm{ml}$ METHANOLIC(B)100 $\mu \mathrm{g} / \mathrm{ml}$ METHANOLIC (C) $50 \mu \mathrm{g} / \mathrm{ml}$ AQUEOUS (D) $100 \mu \mathrm{g} / \mathrm{ml}$ AQUEOUS (E) $50 \mu \mathrm{g} / \mathrm{ml} \mathrm{CHLOROFORM} \mathrm{(F)} \mathrm{100 \mu g/ml} \mathrm{CHLOROFORM}$ 


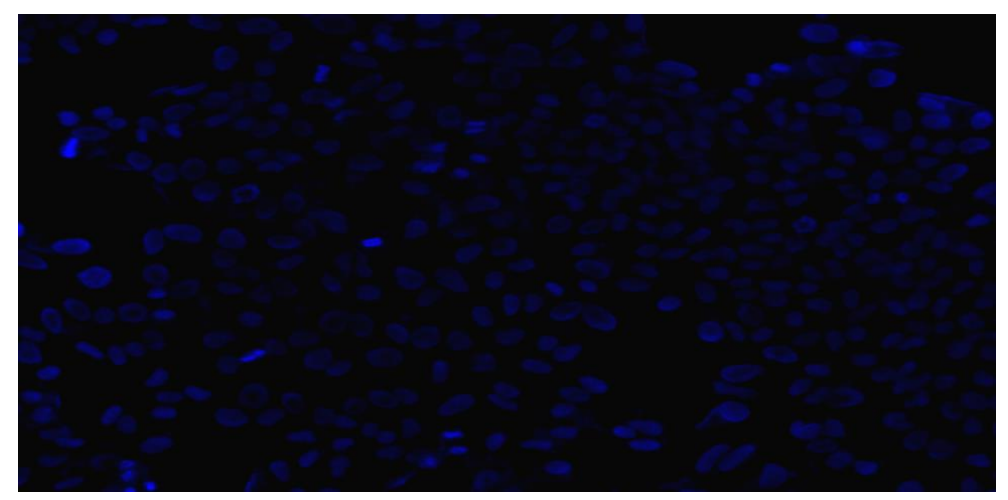

UNTREATED

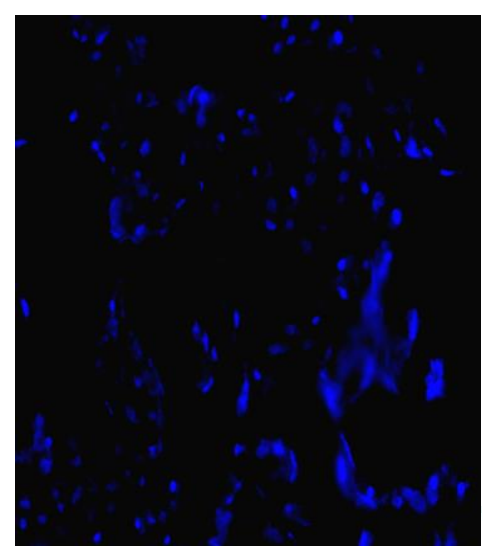

(A)

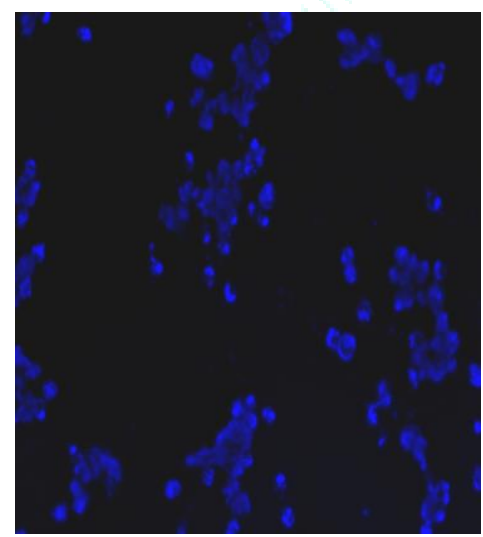

(D)

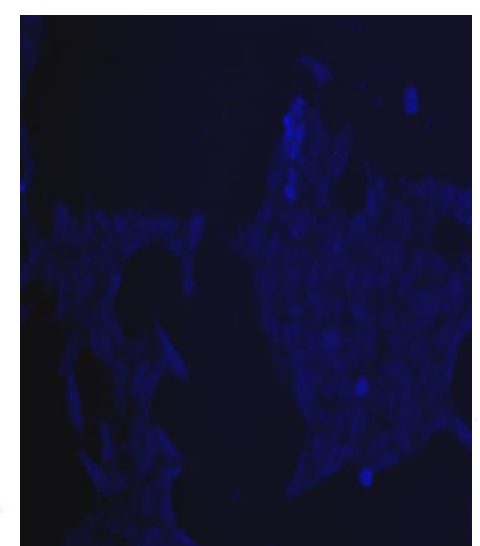

(B)

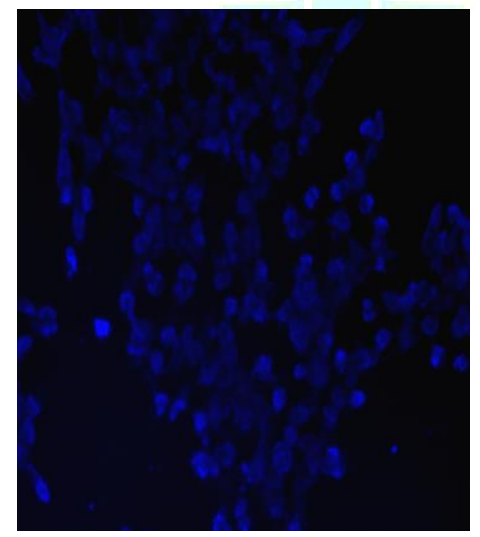

(E)

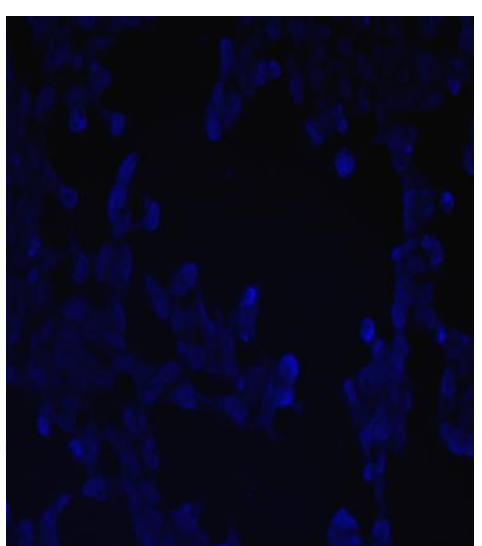

(C)

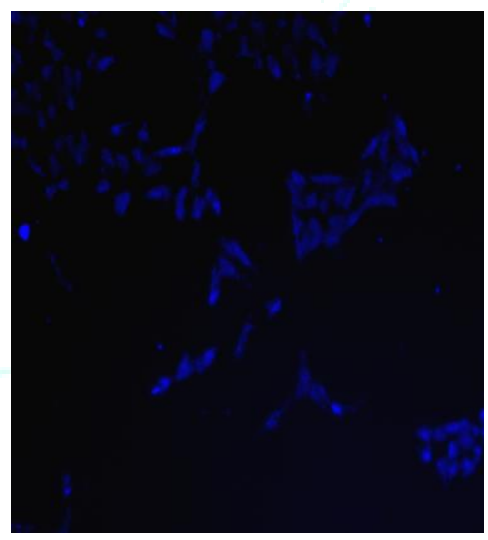

(F)

Fig. 1.2: Nuclei morphological changes of HeLa cells pre-treated with different extracts of Prunus persica(Linn)Batsch leaves followed by staining with DAPI fluorescent dye at $24 \mathrm{~h} .(\mathrm{A}) 50 \mu \mathrm{g} / \mathrm{ml}$ METHANOLIC (B)100 $\mu \mathrm{g} / \mathrm{ml}$ METHANOLIC (C)50 $\mu \mathrm{g} / \mathrm{ml}$ AQUEOUS (D) $100 \mu \mathrm{g} / \mathrm{ml}$ AQUEOUS (E) 50 $\mathrm{gg} / \mathrm{ml}$ CHLOROFORM (F) $100 \mu \mathrm{g} / \mathrm{ml} \mathrm{CHLOROFORM}$

\section{DISCUSSION}

Nowadays, there has been unforeseen interest in the clinical utilization of Phytochemicals as chemotherapeutic agents and various studies have been reported regarding their ability to treat cancer or induce apoptosis. They serve as promising and effective research area with bright future. Breast and Cervical Cancers remains a major global health problem and leading cause of cancer mortalities in most of the countries in the world with approximately 14 million new cases of cancer and 8.8 deaths each year estimated by World Health Organisation. The growing incidence of cancer and high cost, various limitations in the conventional therapy including high cost, and high toxicity of present anticancer drugs has faced a severe challenge to all the researchers to design and develop an alternative, ecofriendly, biocompatible and cost-effective strategy in a greener way. Under this scenario, phytomolecules are expected to revolutionize cancer treatment in the next decade $^{25}$. It is reported that flavonoids exert its cytotoxic activity through apoptosis through signaling pathways to prevent the tumor. Numerous steroid and triterpenoid compounds exhibit cytotoxic properties ${ }^{26}$. The plants of genus Prunus have been reported to suppress the malignant neoplastic cells27. Previous studies also showed that the crude flavonoids caused the inhibition of different cancer cells lines through mechanism involving apoptosis ${ }^{28}$.Apoptosis is a common mode of action of chemotherapeutic agents including plant-derived natural products. Its induction is the key to success of plant derived natural products as anti-cancer agents ${ }^{29}$.Phytochemical analysis in this study has revealed the presence of alkaloids,tannins,Saponins, steroids and flavonoids. After 
treatment with different extracts against various cell lines, the increase of apoptotic cells including the characteristics of apoptotic cells and evident DNA fragmentations were observed which are the important hallmarks of apoptosis. Whereas, the control groups showed no increase of apoptotic cells and no evident of DNA fragments, it was indicated that extracts of Prunus persica leaves could specifically induce apoptosis of cancer cells. The purpose of the investigation was to resolve whether the different extracts exerted an inhibitory effect on cancer cell proliferation and caused cell death. The results of the studies revealed that the Chloroform extract have tremendous apoptotic activity on MDA-MB-231 cells and methanolic extract have good apoptotic activity on HeLa cells. Thus, the current work clearly indicates that Methanolic, Aquous and Chloroform extracts of Prunus persica leaves could be a novel potent cancer chemopreventive or chemotherapeutic agent for human cancer because of its promising activity and may be considered for further clinical studies in drug development.

\section{CONCLUSION}

In the present work, we have explored the therapeutic effect of Prunus persica leaf extracts in three different organic solvents; Chloroform, Water and methanol on two different cell lines i.e MDA-MB-231 and HeLa. The Chloroform extract has shown more effectiveness and less toxicity against MDAMB-231 and Methanol extract was more apoptotic against HeLa in comparison to others.The phytochemical screening also reveals the presence of alkaloids and terpenoids which may be similar to previously isolated phytochemicals from the stem bark of the same plant. The most potent Chloroform extract exhibits anticancer activity by inducing apoptosis (morphology change, nuclear fragmentation, and DNA fragmentation) and cell toxicity in MDA-MB-231 and HeLa cells. Therefore, our data confirm the potential of Prunus persica leaf extract as a source for the development of future chemotherapeutic agents. The current findings will give precious information for its potential application in Breast and cervical cancer treatment in the upcoming years. Based on the present study, researchers can translate these compounds to in vivo cancer study by using different animal models. The subject area of this animal model will spread out the doorways for the researchers to find out the exact mechanism of action of the active compound as one of the potential candidates for the cancer treatment.

\section{Conflicts of Interest: None}

\section{REFERENCES}

1. Iqbal J, Abbasi BA, Mahmood T, Kanwal S, Ali B, Shah SA, Khalil AT. Plant-derived anticancer agents: A green anticancer approach. Asian Pacific Journal of Tropical Biomedicine. 2017 Dec 1;7(12):1129-50.

2. Aung TN, Qu Z, Kortschak RD, Adelson DL. Understanding the effectiveness of natural compound mixtures in cancer through their molecular mode of action. International journal of molecular sciences. 2017 Mar;18(3):656.

3. Thakore P, Mani RK, Kavitha SJ. A brief review of plants having anti-cancer property. Int J Pharm Res Dev. 2012;3:129-36.

4. Weaver BA. How Taxol/paclitaxel kills cancer cells. Molecular biology of the cell. 2014 Sep 15;25(18):2677-81.

5. Singh S, Sharma B, Kanwar SS, Kumar A. Lead phytochemicals for anticancer drug development. Frontiers in plant science. 2016 Nov 8;7:1667.

6. Tariq A, Sadia S, Pan K, Ullah I, Mussarat S, Sun F, Abiodun 00, Batbaatar A, Li Z, Song D, Xiong Q. A systematic review on ethnomedicines of anti-cancer plants. Phytotherapy Research. 2017 Feb;31(2):202-64.
7. Rosangkima G, Prasad SB. Antitumour activity of some plants from Meghalaya and Mizoram against murine ascites Dalton's lymphoma.

8. Siddikuzzaman, Berlin GV. Evaluation of immunomodulatory and antitumor activity of all trans retinoic acid (ATRA) in solid tumor bearing mice. Immunopharmacology and immunotoxicology. 2013 Feb 1;35(1):110-8.

9. Kerr JF, Wyllie AH, Currie AR. Apoptosis: a basic biological phenomenon with wideranging implications in tissue kinetics. British journal of cancer. 1972 Aug;26(4):239-57.

10. Majno G, Joris I. Apoptosis, oncosis, and necrosis. An overview of cell death. The American journal of pathology. 1995 Jan;146(1):3.

11. Fukui K, Werner $C$, Pestel G. Influence of anesthesia procedure on malignant tumor outcome. Der Anaesthesist. 2012 Mar;61(3):193-201.

12. Kang SJ, Ji HY, Lee BJ. Anticancer activity of undecapeptide analogues derived from antimicrobial peptide, Brevinin-1EMa. Archives of pharmacal research. 2012 May 1;35(5):791-9.

13. Sánchez-Aragó M, Formentini L, Cuezva JM. Mitochondriamediated energy adaption in cancer: the H+-ATP synthasegeared switch of metabolism in human tumors. Antioxidants \& redox signaling. 2013 Jul 20;19(3):285-98.

14. Brown JM, Attardi LD. The role of apoptosis in cancer development and treatment response. Nature reviews cancer. 2005 Mar;5(3):231-7.

15. Mishra S, Ahmad S, Kumar N, Sharma BK. Annona muricata (the cancer killer): a review. Glob J Pharma Res. 2013 Mar 31;2(1):1613-8.

16. Heinrich M, Bremner P. Ethnobotany and ethnopharmacy-their role for anti-cancer drug development. Current Drug Targets. 2006 Mar 1;7(3):239-45.

17. Thirumal $M$, Kishore G, Prithika $R$, Das $S$, Nithya G. In vitro anticancer activity of Tecoma stans (L) ethanolic leaf extract on human breast cancer cell line (MCF-7). Intl. J. Pharma and Bio Sci. 2012;2(4):488-93.

18. Cragg GM, Newman DJ. Plants as a source of anti-cancer agents. Journal of ethnopharmacology. 2005 Aug 22;100(1-2):72-9.

19. Tabin S, Kamili AN, Gupta RC. Morphological studies and development of ex-situ protocol for rehabilitation of threatened Rheum species under nursery conditions. Current Botany. 2016 May 27:17-26.

20. Edrah S, Alafid F, Kumar A. Preliminary phytochemical screening and antibacterial activity of Pistacia atlantica and Prunus persica plants of Libyan origin. Int J Sc Res. 2013;4(2):1552-5.

21. Kokate CK. Pharmacognosy edition thirtieth published by Nirali Prakashan Pune.

22. N.Raman, "Phytochemical techniques, New Delhi", pp. 19- 22, 2006.

23. Patel RM, Patel SK. Cytotoxic activity of methanolic extract of Artocarpus heterophyllus against A549, Hela and MCF-7 cell lines. Journal of Applied Pharmaceutical Science. 2011 Sep 1;1(7):167-71.

24. Atale N, Gupta S, Yadav UC, Rani V. Cell-death assessment by fluorescent and nonfluorescent cytosolic and nuclear staining techniques. Journal of microscopy. 2014 Jul;255(1):7-19.

25. Iqbal J, Abbasi BA, Mahmood T, Kanwal S, Ali B, Shah SA, Khalil AT. Plant-derived anticancer agents: A green anticancer approach. Asian Pacific Journal of Tropical Biomedicine. 2017 Dec 1;7(12):1129-50.

26. Thakur M, Melzig MF, Fuchs H, Weng A. Chemistry and pharmacology of saponins: special focus on cytotoxic properties. Botanics: Targets and Therapy. 2011;1:19-29.

27. Bailly C. Anticancer properties of Prunus mume extracts (Chinese plum, Japanese apricot). Journal of ethnopharmacology. 2020 Jan 10; 246:112215.

28. Brusselmans K, Vrolix R, Verhoeven G, Swinnen JV. Induction of cancer cell apoptosis by flavonoids is associated with their ability to inhibit fatty acid synthase activity. Journal of Biological Chemistry. 2005 Feb 18;280(7):5636-45.

29. Sreelatha S, Jeyachitra A, Padma PR. Antiproliferation and induction of apoptosis by Moringa oleifera leaf extract on human cancer cells. Food and Chemical Toxicology. 2011 Jun 1; $49(6): 1270-5$ 